\title{
Teachers' and students' perception of their roles in the teaching and learning of science
}

\author{
Dennis Agama Eka \\ Department of Biology, College of Education, Oju, P.M.B. 2035 Otukpo, \\ Benue State, Nigeria
}

\begin{abstract}
This study examined the perception of science teachers and students in teaching and learning from role identification perspectives. A survey design was used for the study. The sample consisted of 140 teachers and 270 students from nine selected schools that offer science in Benue State. To guide the study, three research questions were raised, while three hypotheses were formulated and tested. A 50item and 30-item questionnaires for teachers and students respectively were developed and validated as instrument for data collection. These have reliability coefficient of 0.98 and 0.93 for teachers and students respectively. The data collected were analyzed using mean, standard deviation, t-test and correlation coefficient. The result revealed a mismatch between the perceived and expected roles of science teachers and students. The mean of 4.08 and standard deviation of 0.39 for teachers and a mean of 4.40 and standard deviation of 0.43 for students have revealed that teachers are more mismatched than students. The result also revealed that, the perception of male and female teachers do not differ significantly ( $\mathrm{r}=0.08$ for male, while $\mathrm{r}=0.75$ for females). It was recommended that emphasis be laid on role identification in teachers' pre and in-service training and teachers should recognize that their job subjects them to greater responsibility than their students.
\end{abstract}

Keywords: science teachers; teaching and learning; students

\section{INTRODUCTION}

The standard of education in Nigeria has remained an issue of concern to many well meaning Nigerians. Some people said the standard is higher than what it was; others said the standard is lower than what it was. Whatever is the opinion of any individual, the outcome of educational programmes is what one can consider in making decision about this. That is, the graduates we are turning out of our educational institutions. Solarin in Sulaiman (2003) discussed the standard of education in Nigeria and argued whether the standard is falling or it has fallen. People in the academia, employers of labour, business and many others have joined in the argument on the unsatisfactory standard of education in Nigeria.

There has also been argument on who is responsible for the lack luster standard of education in Nigeria. Teachers, students, parents and the entire society have a stake in education and so the roles the various groups of people play may have a close relationship with the development, degeneration or improvement of education. Teaching and learning brings about the acquisition of desired experience needed for the achievement of the goals of the society. The National Policy on Education (2004) defines education as a process which helps to develop 
the whole man to enable him function effectively in whatever environment he finds himself. To achieve this, teaching and learning occupies the central position.

Science is one area of education that has suffered a lot of 'neglect' over the years due to inadequate funding by Government and students' attitude towards learning (Adeoye 2001). At best we hear a lot about how useful science is and how the government plans to under-budget to improve it. Students' attitude to the study of sciences also leaves much to be desired. Science subjects are generally perceived difficult by many students.

Eniayeju, Abiodun and Eniayeju (2006) asserted that science, technology and mathematics (STM) are often perceived by students as difficult courses and that the difficulties are related to the subjects themselves and the usual methods of teaching used by teachers which in most cases do not give any regard to the psychological level of children's learning. This learning problem has become the concern of science Teachers Association of Nigeria. Like Eka (2008) said, this learning problem is one of the reasons why STM teachers especially under the umbrella of science Teachers Association of Nigeria (STAN), usually come together annually to brainstorm, review as well as discuss effective methods of teaching these subjects and resources available for effective teaching and learning processes.

Teaching and learning involves both teachers and students under the auspices of a school. The teacher has a message to deliver to the students while the students have the responsibility to engage, participate and study to acquire knowledge. Teaching as viewed by many people in the society is an act of imparting knowledge on the learners. However, teaching involves much more than that. To be effective, the teaching process should involved the whole personality of the teacher, his way of life, leadership style, counseling capacity, intellectual capability, relationship with colleagues and more. According to Obilom and Ukachi (2004), teaching is the guidance of learning activities.

They further stressed that teaching is a complex art and science of guiding the pupils through a variety of selected experience to bring about a worthwhile change in behaviour. To them as a science, it involves processing of a body of specialized knowledge. In support of this views Oyetunde (2004), asserted that teaching is an active, constructive process in which the teacher assumes the role of a strategic planner, making decisions about the content and appropriate instructional strategies. In teaching, the core of its professionalism is best defined and described not in terms of pay or status or qualifications, but in terms of distinctive kind of actions and judgments that professionals make (Fullan and Hargreaves, 2001).

Mangal (2007) described learning as the acquisition of habits, knowledge and attitude that represents progressive change in behaviour. Learning involves new ways of doing things. It entails a permanent change in behaviour of organisms due to experience. Change in behaviour as a result of fatigue, illness, alcohol, drugs, physical maturation etc are however not regarded as learning. Mallum and Haggai (2000) Durojaiye (2004) and Adebisi (2006), all describe learning as a permanent change in behavior due to experience.

Perception is an experience that involves the organization of objects, events or relationship leading to the process by which we interpret our sensory input. Silverman in Mangal (2007) defines perception as "an individual's" awareness aspect of behaviour; for it is the way each person processes the raw data he or she receives from the environment into a meaningful pattern".

He further looked at perception in terms of process, information extractor, preparation to response, sensation, provision of organization and being highly individualized. The sequence of the process in which perception takes place is shown in the Figure 1. 




Source: Quiun, Alvin, Roy and Chapman (2000).

Fig. 1. Sequence of perception.

Role is the function or position somebody has or expected to have in an organization, a society or in a relationship. Role in this context is the function teachers and students have to play in teaching and learning. According to Durojaye (2004), a role is the part that one plays in life. It is a broadly uniform pattern of behaviour which is specific to a particular position, social situation or social relation.

Each role is a pattern of behaviour which is familiar to those who perform the roles. Certain roles are expected of both teachers and students. Esiobu (2000), Ada and Okwu (2001), Kohl (2001) Durojaije (2004), Muodumogu (2004), Oyetunde (2004), Muodumogu (2007) and Chauhan (2007) in separate publications described some roles teachers and especially science teachers and students ought to play in teaching and learning situation. The expected roles and characteristics or qualities of such roles are discussed as follows:

\section{Teachers' Expected Roles}

1. Leadership role-

\section{Expected Characteristics}



2. Tutoring Role-

lesson selection, presentation and evaluation of lessons, use of effective communication, varied instructional methods, involvement of learners in questioning, giving incentives, understanding the learners, 
3. Managerial Role-

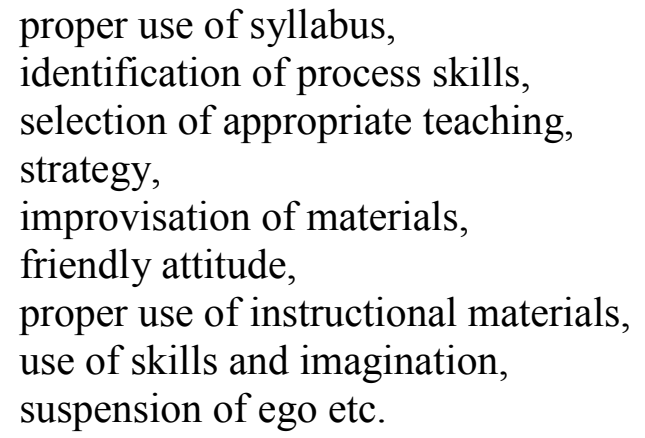

4. Counselling role-

welfare of pupils, guidance, supervision, source of inspiration, motivation, source of encouragement etc.

5. Team working Role _ - tackling of problems together, learning from one another, effort to achieve the aims of education, helping others to grow etc.

\section{Expected Roles of Science Students}

1. Showing of interest in learning,

2. Practice (going over lessons taught),

3. Participation in class activities,

4. Inductive reasoning,

5. Responsibility to learn and acquire knowledge,

6. Ability to comprehend and think through,

7. Ability to analyze learned materials,

8. Paying attention during lessons,

9. Experimentation,

10. Observation,

11. Group studying,

12. Reading and recall,

13. Learning and application of principles,

14. Stimulus-response learning,

15. Memorization of certain concept, 
16. Ability to manipulate instruments,

17. Communication ability,

18. Resourcefulness,

19. Loyalty,

20. Obedience,

21. Thinking,

22. Respect etc.

In as much as these expected roles of science teachers and students may not be exhaustive, if these roles are adhered to, teaching and learning activities can be improved upon. In this study, these roles that are expected of science teachers and students are the main focus and the investigation was made to determine whether there is a mismatch between these expected roles and what science teachers and students actually do on the field.

It is hoped that both teachers and students will be honest enough in their response to indicate the extent to which they play a particular role to enhance teaching and learning activities. This study also looks at the perception of male and female teachers with the views to determine whether there are disparities in their perception. This helps to reveal whether there is gender weakness in level of perception or not.

This research work is an investigation that will help elucidate the perception of teachers and students of their roles in teaching and learning of science. Should there be a mismatch between their perceived and expected roles, the study will clarify.

\section{Research Questions}

The following research questions guided the study:

1. How do teachers perceive their roles in science teaching?

2. How do students perceive their roles in science learning?

3. To what extent is there a mismatch between the teachers' and students' perception of their roles in science teaching and learning?

\section{Statement of Hypotheses}

The following null hypotheses were tested at 0.05 level of significant.

1. There is no significant mismatch between teachers' perceived and expected roles in science teaching.

2. There is no significant mismatch between student's perceived and expected roles in science learning.

3. Perceived role of male and female science teachers do not differ significantly.

\section{METHOD}

This study adopted a survey design. The design was chosen because it attempt to collect information from a number of respondents independently and it also involves gathering data about a target group from which finding obtained from the sample can be used to generalize for the entire population. Survey research is the one in which a group of people or items is studied by collecting and analyzing data from only a few people considered to be a representative of the entire population (Emaikwu 2006). 
The study was carried out in Benue State of Nigeria and the population comprises all science teachers and students. A sample of 140 science teachers and 270 science students were used for the study. This brings the total sample to 410 respondents. The sampled science schools were purposively selected to take care of Government owned and privately owned schools. Science teachers were also purposively selected to take care of gender while students were selected using a random sampling technique. A five-point Likert scale questionnaires on perceived roles was developed for teachers and students respectively. The teachers' instrument was named teachers' perceived role questionnaire (TPRQ), while the students instrument was named, students perceived role questionnaire (SPRQ).

The instruments were structured questionnaires constructed and validated by three experts in science education and one other expert in measurement and evaluation. These experts were university professors and very senior lecturers drawn from Benue State University and University of Agriculture Makurdi. The instruments were pilot tested in five secondary schools that offers science and a Pearson-product moment correlation coefficient ' $r$ ' using split-half method was used to determine its reliability. Therefore, ' $r$ ' for teachers was 0.98 while, that of students was 0.93 . This indicates a high level of reliability and validity. 40 teachers and 90 students were used for the pilot test.

The information from the literature review and empirical studies helped in the selection of the type of design, sampling technique, instrumentation and method of data analysis. The researcher personally visited some schools to collect data whiles four research assistants were trained and used to collect data in other schools. Mean, standard deviations and correlations were used to analyze the data. Since a five point Likert scale was used as questionnaires and because expectations are high, the mean score of expected role was rated 5.00. Any mean score of perceived role below 5.00 is considered not significant. To test for significance of values of correlation coefficient ' $r$ ' a t-test was calculated and tested at probability level of 0.05 . The values obtained were then designated as calculated value of $t$, and was compared with critical value of $t$. if the $t$-calculated value was greater than $t$-critical value, the value of ' $r$ ' was said to be significant at the significance level of 0.05 and vice versa. The hypotheses as stated were then rejected or not rejected as the case may be.

\section{RESULT}

The data collected and analyzed are presented in the order of research questions and hypotheses

\section{1. Research Question One}

How do teachers perceive their role in science teaching? To answer research question one, the data for the perceived role of teachers was statistically analyzed and the result is shown on table one. 
Table 1. Mean value of teachers' perception of their roles.

\begin{tabular}{lccc}
\hline & $\mathrm{N}$ & Mean & Standard Deviation \\
\hline $\begin{array}{l}\text { Teachers' perception } \\
\text { of their roles- }\end{array}$ & 140 & 4.08 & .39 \\
Expected role- & & 5.00 & \\
\hline
\end{tabular}

$\mathrm{N}=$ number of respondents

Table one, shows a mean of 4.08 and a standard deviation of 0.39 which is high in terms of the population of teachers used. The mean score of perceived role (4.08) is less than the mean value of expected role which is 5.00. This shows that teachers' perception is below average.

\section{2. Research Question Two}

How do students perceive their role in science learning? The data collected for the perceived role of students was statistically analyzed and the result is shown on table two.

Table 2. Mean value of students' perception of their roles.

\begin{tabular}{lccc}
\hline & $\mathrm{N}$ & Mean & Standard Deviation \\
\hline $\begin{array}{l}\text { Students' perception } \\
\text { of their roles- }\end{array}$ & 270 & 4.40 & .43 \\
Expected role- & & 5.00 & \\
\hline
\end{tabular}

Table two, shows a mean of 4.40 and a standard deviation of 0.43 which is also high in terms of the population of students used. The mean score of perceived role (4.40) is less than the mean score of expected role which is 5.00. This indicates that students' perception is below average.

\section{3. Research Question Three}

To what extent is there a mismatch between teachers' and students' perception of their roles in science teaching and learning? The data collected for the perceived role of teachers and students were statistically analyzed and correlated to indicate the extent of mismatch. This is shown in Tables 3 and 4. 
Table 3. Mean value of teachers' and students' perception of their roles in science teaching and learning.

\begin{tabular}{lccc}
\hline & $\mathrm{N}$ & Mean & Students Deviation \\
\hline & 140 & 4.08 & .39 \\
Teachers' perception of their roles & 270 & 4.40 & .43 \\
Students' perception of their roles- & & 5.00 & \\
Expected role- & & & \\
\hline
\end{tabular}

Table 4. Correlation between teachers' and students' perceived role.

\begin{tabular}{cccc}
\hline Correlations & Teachers & Students & Significance \\
\hline Teachers & 1.00 & 0.04 & \\
$(\mathrm{~N}=140)$ & & & \\
Students & & 1.00 & 0.82 \\
$(\mathrm{~N}=270)$ & & & \\
\hline
\end{tabular}

For teachers $r=0.04$

For students $r=0.82$

The correlation indicates 0.04 for teachers and 0.82 for students. This shows that students' role perception is higher than that of the teachers. Teachers are therefore more mismatched in identifying their roles.

\section{4. Hypothesis One}

There is no significant mismatch between the teachers' perceived and expected role in science teaching.

Table 5. Result of t-test analysis of teachers' perceived and expected roles.

\begin{tabular}{lcccccccc}
\hline & Mean & SD & df & p & t-cal & t-crit & sig.(2 tail) & Decision \\
\hline Teachers' perception & 4.08 & 0.39 & 139 & 0.05 & 3.95 & 1.64 & .00 & Rejected \\
Of their roles & 4.08 & & & & & & & \\
Expected role & 5.00 & & & & & & \\
\hline
\end{tabular}

$\mathrm{SD}$-standard Deviations, $\mathrm{df}=$ Degree of freedom, $\mathrm{p}=$ probability $\mathrm{t}$-cal $=\mathrm{t}$-calculated and $\mathrm{t}$-crit $=\mathrm{t}$-critical value.

The null hypothesis was tested for significance at $\mathrm{p}=0.05$ and the appropriate data as correlated indicates a linear relationship between the perceived and expected roles. This is 
perfect correlation (1.00 see Table 4). It is therefore significant, and this means teachers that, knows their role could perform high in class. From Table 5, the t-calculated value of 3.95 is greater than the $\mathrm{t}$-critical value which is 1.64 at $\mathrm{df}=139$ and $\mathrm{p}=0.05$. The null hypothesis is therefore rejected.

\section{4. Hypothesis Two}

There is no significant mismatch between the students' perceived and expected roles in science learning.

Table 6. Result of t-test analysis of students' perceived and expected roles.

\begin{tabular}{lcccccccc}
\hline & Mean & SD & df & p & t-cal & t-crit & sig.(2 tail) & Decision \\
\hline Students' perception & & & & & & & & \\
Of their roles & 4.40 & 0.43 & 269 & 0.05 & 4.45 & 1.64 & .00 & Rejected \\
Expected role & 5.00 & & & & & & & \\
\hline
\end{tabular}

The null hypothesis was tested for significance at $\mathrm{p}-0.05$ and the appropriate data as correlated indicate a relationship between the perceived and expected roles. From the table 6 , the $t$-calculated value of 4.45 is greater than the $t$-critical value of 1.64 at $\mathrm{df}=269$ and $\mathrm{p}=0.05$. The null hypothesis was rejected. That is, disparities exist between the perceived and expected roles of students.

\section{5. Hypothesis Three}

Perceived role of male and female teachers do not differ significantly.

Table 7. Correlation of male and female teachers' perception of their roles.

\begin{tabular}{ccccc}
\hline Correlations & male & female & sig & Decision \\
\hline Male & 1.000 & 0.08 & & \\
$(\mathrm{~N}=75)$ & & & & not rejected \\
Female & & 1.000 & 0.00 & \\
$(\mathrm{~N}=65)$ & & 0.75 & \\
\hline
\end{tabular}

For male $\mathrm{r}=0.08$, For female $\mathrm{r}=0.75$

From Table 7, the correlation for male is 0.08 while that of female is 0.75 both of which are significant. This is because in correlation any figure that lies between 0.00 and 1.00 are significant. The result indicates a better perception on the part of female teachers but the perception, of male and female teachers are both significant. The null hypothesis is therefore not rejected. Perception does not depend on gender. 


\section{DISCUSSION}

This study was designed to find out the perception of teachers and students in science teaching and learning. The findings have shown that disparities exist between the perceived and expected role of teachers in science teaching. This means that many science teachers are not doing exactly what they are expected to do in science teaching. This study has already revealed that teaching involves much more than classroom instruction. It involves guidance, supervision, team work, leadership, administration and more, Uhana (2007) investigated teachers' perception of the objectives of instructional supervision and discovered that teachers' perception falls below what is contained in the National Policy on education. In line with this, Heever (2001), Wally (2001) and Fullan and Hargreaves (2001) in separate publications all agreed that the decay in educational system has been accompanied by many teachers losing a sense of the distinctive kind of service they should be offering to the community.

The finding of this study has also indicated a mismatch between the perceived and expected role science students. This agrees with the work of Muodumogu (2007) who found out that teachers perceived poor comprehension strategy, lack of concentration poor memory and inadequate knowledge of language of instruction as learning problems of students. The study though has indicated some disparities between male and female teachers, it does not show that perception is gender biased. Teachers and students commitment to teaching and learning will continue to form basis for student's achievements.

\section{CONCLUSIONS AND RECOMMENDATIONS}

This study has addressed issues of teaching and learning from role identification perspectives. The result of the study has indicated disparities between science teachers' and students' perceived and expected roles. This study has therefore confirmed that wrong perception of science teachers and students of their roles is one of the causes of the continued unsatisfactory standard of education in Nigeria. The study has also revealed that there is no much difference in the perception of male and female science teachers. It is therefore recommended that:

i. Retraining of teachers should be emphasized. This could be done through organized workshops and seminars with specific aim of training teachers on the role they are expected to play in teaching and learning situation.

ii. Proper orientation should be conducted for the newly admitted students with emphases on how they should study to learn

iii. Science teachers must recognize that their job is not merely an economic venture but it is much more. They must realize that they are subject to greater responsibility than their students.

\section{References}

[1] Ada N. A., Okmu E. I., Benue State University Journal of Education 3(1\&2) (2001) 214-223.

[2] Adebisi D. O. (2006). Introduction to Psychology. Ibdan; College Press and Publisher Ltd.

[3] Adeoye J. A., Journal of Research in Curriculum 1(2) (2001) 20-22. 
[4] Chauhan S. S. (2007). Advanced Educational Psychology. New Delhi: Vicas Publishing House PVT Ltd.

[5] Durojaiye, M.O.A. (2004). A New Introduction to Educational Psychology. London: Evans brothers Ltd.

[6] Eka, D.A. (2008). Resources and Infrastructural Issues in Science Technology and Mathematics Education (STME) in Nigeria. In Omonu, J.B., Andu, T.A., Agashi, P.P., Musa, S.A., Ejima, S.O. \& Onimisi, J.A. (Eds). Educational Reforms and the Sustainability of Standards in STME in Nigeria. Lagos: Sam Artrade.

[7] Emaikwu,S.O. (2006). Fundamentals of Educational Research Methods and Statistics. Kaduna: Deray Prints Ltd.

[8] Eniayeju, P.A., Abiodun, J.A \& Eniayeju, A.A. (2000). An evaluation of STM resources material usage in Kano; Things are seldom what they seem. Science Teachers Association of Nigeria; $41^{\text {st }}$ annual Conference Proceedings. Heinemann Educational books (Nig) Plc.

[9] Esiobu, G.O. (2000). Biology teachers' Awareness and level of use of Mental Analogies in teaching difficult Concepts in Biology. Science Teachers Association of Nigeria; $41^{\text {st }}$ Annual Conference Proceedings Heinemann Educational books (Nig) Plc.

[10] Federal Republic of Nigeria (2004). National Policy on Education. Abuja; Gossamer Communications.

[11] Fullan, M.\& Hargreaves, A. (2001). The Teacher's purpose. In Adendorff, M., Gultig, J. \& Mason, M. Being a teacher; Professional Challenges and Choices. Cape Town: Oxford University Press.

[12] Heever, R.V. (2001). Teachers want what Students Need. In Adendorff, M., Gultig, J. \& Mason, M. Being a Teacher; Professional Challenges and Choices: Cape Town: Oxford University Press.

[13] Kohl, H. (2001). On becoming a Teacher. In Adendorff, M., Gultig, J. \& Mason, M. Being a teacher; Professional Challenges and Choices. Cape Town: Oxford University Press.

[14] Mallum, J.O., \& Haggai, M.P. (2000). Educational Psychology Classroom Practice; Jos: Ya-byangs publishers.

[15] Mangal, S.K. (2007). An Introduction to Psychology. New Delhi: Sterling Publishers Private Ltd.

[16] Muodumogu C. A., Journal of research in curriculum and Teaching 2(1) (2007) 83-94.

[17] Obilom J. E. C., Ukachi R. A., Journal of Educational studies; institute of Education University of Jos 10(1) (2004) 166-176.

[18] Oyetunde, T.P. (2004). Understanding Teaching and Learning Process. In Andzayi, C.A; Mallum, Y.A, \& Oyetunde, T,O. (Eds). The Practice of Teaching; Perspectives and Strategies. Jos: Lecaps Publishers.

[19] Quiun, A.S., Alvin, J. N., Roy, J.S. \& Chapman, H.M. (2000). Psychology; understanding human behaviour ( $3^{\text {rd }}$ Ed). New York: McGraw-Hill book company.

[20] Sulaiman, B. (2003). Education for Greatness; Selected Speeches of Tai Solarin. Lagos: Spiro sensual W \& W Ltd.

[21] Uhana J. O., Journal of research in curriculum and teaching 2(1) (2007) 137-142.

[22] Wally, M. (2001). A culture of Teaching. In Adendorff, M., Gultig, J. \& Mason, M. Being a teacher; Professional Challenges and Choices. Cape Town: Oxford University Press.

[23] Tomáš Hes, Anna Poledňáková, International Letters of Social and Humanistic Sciences 2 (2013) 18-31. 
[24] Mohsen Mehrara, Masoumeh zirak, International Letters of Social and Humanistic Sciences 2 (2013) 32-38.

[25] Taiwo Adewale Muritala, Ismail O. Fasanya, International Letters of Social and Humanistic Sciences 2 (2013) 39-50.

[26] Borowski A., International Letters of Social and Humanistic Sciences 3 (2013) 46-53.

[27] Borowski A., International Letters of Social and Humanistic Sciences 3 (2013) 69-74.

[28] Donovan A. McFarlane, International Letters of Social and Humanistic Sciences 4 (2013) 35-44.

[29] Rajesh K. Yadav, Nishant Dabhade, International Letters of Social and Humanistic Sciences 4 (2013) 49-69.

[30] Borowski A., International Letters of Social and Humanistic Sciences 4 (2013) 70-74.

[31] Paul Bukuluki, International Letters of Social and Humanistic Sciences 5 (2013) 27-44.

[32] Mohsen Mehrara, Maysam Musai, International Letters of Social and Humanistic Sciences 5 (2013) 55-62.

[33] Debiprasad Mukherjee, International Letters of Social and Humanistic Sciences 6 (2013) 41-48.

[34] Tomáš Hes, Alena Neradová, Karel Srnec, International Letters of Social and Humanistic Sciences 7 (2013) 55-75.

[35] Kinga Dziwańska, International Letters of Social and Humanistic Sciences 7 (2013) 96-112.

[36] Borowski A., International Letters of Social and Humanistic Sciences 7 (2013) 113-118.

[37] Mohsen Mehrara, Maysam Musai, International Letters of Social and Humanistic Sciences 8 (2013) 1-7.

[38] Tittenbrun J., International Letters of Social and Humanistic Sciences 11 (2013) 10-34.

[39] Mohsen Mehrara, Hamid Abrishami, Mostafa Boroujli, Mahan Amin, International Letters of Social and Humanistic Sciences 11 (2013) 76-83.

[40] Borowski A., International Letters of Social and Humanistic Sciences 11 (2013) 100-105.

[41] Morteza Amani, Mahmood Goodarzi, Hamze Ahamadian, International Letters of Social and Humanistic Sciences 1 (2014) 7-13.

[42] Seyed Mohammad Marandi, Hossein Pirnajmuddin, International Letters of Social and Humanistic Sciences 1 (2014) 14-27.

[43] Elias Olukorede Wahab, Chioma Joan Ikebudu, International Letters of Social and Humanistic Sciences 1 (2014) 28-42.

[44] Bahram Meihami, Zeinab Varmaghani, Hussein Meihami, International Letters of Social and Humanistic Sciences 1 (2014) 43-5.

[45] Francis Briggs, Elizabeth Desmond, International Letters of Social and Humanistic Sciences 1 (2014) 71-80.

[46] Liverpool E. Onyije, Jacinta A. Opara, International Letters of Social and Humanistic Sciences 1 (2014) 81-87

[47] Sele Sylvester Ebisin, International Letters of Social and Humanistic Sciences 2 (2014) $1-9$.

[48] Tittenbrun J., International Letters of Social and Humanistic Sciences 2 (2014) 20-40.

[49] Borowski A., International Letters of Social and Humanistic Sciences 2 (2014) 110-121.

[50] Pawa Tersoo, International Letters of Social and Humanistic Sciences 3 (2014) 26-36.

[51] Rabi'u Muhammad Ishaq, International Letters of Social and Humanistic Sciences 3 (2014) 37-44. 
[52] Adoga James Ada, International Letters of Social and Humanistic Sciences 3 (2014) 45-52.

[53] Bahram Meihami, Hussein Meihami, International Letters of Social and Humanistic Sciences 3 (2014) 80-91.

[54] Kabiru Ibrahim Yankuzo, International Letters of Social and Humanistic Sciences 4 (2014) 1-8.

[55] Onyike Maggaret Odu, International Letters of Social and Humanistic Sciences 4 (2014) 31-39.

[56] Uloma Charity Oguzor, International Letters of Social and Humanistic Sciences 4 (2014) 97-104.

[57] Okezie A. Ihugba, Alex Odii, A. C. Njoku, International Letters of Social and Humanistic Sciences 5 (2014) 21-34.

[58] Okezie A. Ihugba, Bankoli Bankong, N. C. Ebomuche, International Letters of Social and Humanistic Sciences 5 (2014) 92-113.

[59] Borowski A., International Letters of Social and Humanistic Sciences 6 (2013) 86-90. 